\title{
Berdamai dengan Hutan; Memberdayakan Kelompok Tani Dusun Sodong Ponorogo sebagai Agen Substitusi Pangan
}

\author{
Hendra Afiyanto \\ Institut Agama Islam Negeri Ponorogo \\ Email: afianto@iainponorogo.ac.id
}

\begin{abstract}
The cutting of the poverty chain is done through providing entrepreneurial insight to the farmer groups that is an agricultural sector of cassava super that is able to provide bigger income to improve the economic level of the community. The development of entrepreneurial spirit will automatically cut the unemployment class, the working class of Sodong village Sampung sub-district Ponorogo regency. Later, with the emergence of many cassava super entrepreneurs, people's income will increase. The increasing income of the community is related to the increasing level of education of the younger generation. If the level of education has begun to increase, the poverty rate will gradually be reduced in the following year. This paper concludes that Sodong farmers which are actually part of a social group, in a community stigmatized as looters and forest destroyers. Even if it is empowered with a structured plan, this stigma can be eliminated. The farmers should be able to be used as an agent to socialize various processed cassava products as food crops to replace rice.
\end{abstract}

Abstrak: Pemotongan mata rantai kemiskinan bisa dilakukan melalui pemberian wawasan kewirausahaan kepada kelompok tani bahwa ada sektor pertanian singkong dengan varietas gajah yang mampu memberikan income lebih untuk meningkatkan taraf ekonomi masyarakat. Berkembangnya jiwa wirausaha akan secara otomatis memangkas kelas pengangguran, kelas buruh masyarakat KT dsn. Sodong, kec. Sampung. Nantinya dengan banyak munculnya wirausahawan singkong gajah maka pendapatan masyarakat meningkat. Peningkatan pendapatan masyarakat berelasi dengan meningkatnya tingkat pendidikan generasi muda. Jika tingkat pendidikan sudah mulai mengalami peningkatan maka secara perlahan angka kemiskinan ditahun berikutnya sedikit dapat dikurangi. Tulisan ini menyimpulkan bahwa kelompok tani Dusun Sodong yang notabene merupakan bagian dari kelompok sosial, di masyarakat distigma sebagai penjarah dan perusak hutan. Padahal jika diberdayakan dengan rencana terstruktur maka stigma ini dapat dihilangkan. Kelompok tani tersebut seharusnya bisa dimanfaatkan sebagai agen untuk memasyarakatkan berbagai hasil olahan singkong sebagai tanaman pangan pengganti beras.

Kata Kunci: Kelompok Tani, Singkong Gajah, Wirausaha. 


\section{PENDAHULUAN}

Badegan Kelompok Tani (K'T) merupakan kelompok sosial yang jarang tersentuh modernitas dari luar, baik modernitas dalam bentuk diversifikasi hasil hutan dan teknik pengelolaan hasil hutan. Begitu juga dengan KT dsn. Sodong, kec. Sampung yang masih sangat sederhana dalam mengelola hasil hutan. Kurangnya pemberdayaan dan adanya mindset bahwa masyarakat KT di pedesaan akan sulit ber-relasi dengan unsur-unsur pembangunan membuat dsn. Sodong, kec. Sampung jarang tersentuh modernitas dari luar. Padahal sistem sambatsinambat, tolong-menolong, atau gotong royong masyarakat pedesaan juga merupakan modal pembangunan (Kartodirjo, 1993: 159).

Pentingnya memberdayakan K'T dsn. Watubonang karena KT adalah kelompok tani yang jarang mendapat perhatian pemerintah. Jika melihat data BPS kabupaten Ponorogo tahun 2016 mayoritas matapencaharian masyarakat dsn. Sodong, kec. Sampung adalah sektor pertanian. Jadi sudah seharusnya ada pemberdayaan sektor pertanian khususnya hasil hutan. Umumnya KT dsn. Sodong, kec. Sampung mengusahan hasil hutan berupa ubi kayu atau singkong sebagai komoditas utama hasil hutannya. Pada tahun 2015 hasil singkong untuk keseluruhan kecamatan Badegan sebanyak 62. 124 kwintal. Singkong menempati posisi kedua sebagai komoditas pertanian utama setelah padi sebanyak 159.682 kwintal (BPS Kabupaten Ponorogo, 2016).

Dalam kehidupan sehari-hari, masih adanya anggapan bahwa kewirausahaan identik dengan apa yang dimiliki baru dilakukan atau wiraswasta. Pandangan tersebut kurang tepat, karena jiwa dan sikap kewirausahaan tidak hanya dimililiki oleh usahawan akan tetapi dapat dimiliki oleh setiap orang yang berpikir kreatif dan bertindak inovatif baik kalangan usahawan maupun masyarakat umum seperti petani, buruh, mahasiswa, pengangguran, dan lainnya (Suryana, 2003: 1).

Kewirausahaan adalah kemampuan kreatif dan inovatif yang dijadikan dasar, kiat, dan sumber daya untuk mencari peluang menuju sukses. Inti dari kewirausahaan adalah kemampuan untuk menciptakan sesuatu yang baru dan berbeda melalui berpikir kreatif, dan bertindak inovatif untuk menciptakan peluang. Sukses dalam kewirausahaan akan tercapai apabila berpikir dan melakukan sesuatu yang baru atau sesuatu yang lama dengan cara-cara baru (Suryana, 2003: 2).

Tentunya defini kewirausahaan secara universal ini harus kita komparasikan dengan pendapat ahli. Perkembangan teori dan istilah enterpreneur adalah sebagai berikut: 
a. Abad pertengahan: Berarti aktor atau orang yang bertanggung jawab dalam proyek produksi berskala besar.

b. Abad 17 diartikan sebagai orang yang menanggung resiko untung rugi dalam mengadakan kontrak pekerjaan dengan pemerintah dengan menggunakan fixed price.

c. Tahun 1725 Richard Cantillon menyatakan enterpreneur sebagai orang yang menanggung resiko yang berbeda dengan orang memberi modal.

d. Tahun 1797, Bedeau menyatakan wirausaha sebagai orang yang menanggung resiko, yang merencanakan, supervisi, mengorganisasi, dan memiliki.

e. Tahun 1803, Jean Baptist Say menyatakan adanya pemisahan antara keuntungan untuk wirausaha dan keuntungan untuk pemilik modal.

f. Tahun 1876, Francis Walker membedakan antara orang yang menyediakan modal dan menerima bunga, dengan orang yang menerima keuntungan karena keberhasilannya memimpin usaha.

g. Tahun 1934, Joseph Schumpter, seorang wirausaha adalah seorang inovator dan mengembangkan teknoilogi.

h. Tahun 1961, David McLelland, enterpreneur adalah seorang yang mampu menanggung resiko.

i. Tahun 1964, Peter Drucker, enterpreneur adalah seorang yang mampu memanfaatkan peluang.

j. Tahun 1975, Albert Shapero, seorang yang memilikin inisiatif, mengorganisir mekanis sosial dan ekonomi, dan menerima resiko kegagalan.

k. Ahun 1980, Karl Vesper seorang wirausaha berbeda dengan ahli ekonomi, Psikologis, Business Person, dan politikus.

1. Tahun 1883, Gifford Pinchot, wirausaha adalah seorang enterpreneur dari dalam organisasi yang sudah ada/ organisasi yang sedang berjalan.

m. Tahun 1985, Robert Hisrich: Enterpreneur is the process of creating something different with value bay devoting the necessary time and effort, assuming the accompanying financial, psycological, and social risk and receiving the resulting rewards of monetary and personal satisfaction. (Robert D. Hisrich dan Michael P. Peters, 1995:6).

Secara etimologi kewirausahaan berasal dari gabungan dua kata yakni wira dan usaha. Wira diartikan sebagai sifat jantan, laki-laki, pahlawan, perwira, pejuang, manusia unggul, teladan, berbudi luhur, berwatak agung, gagah, dan berani (Poerwadarminta, 1999:1151). Sedangkan usaha megandung arti ikhtiar, perbuatan, prakarsa, dan daya upaya (Poerwadarminta, 1999:1136). 
Kewirausahaan dapat diartikan sebagai hal-hal yang bersangkutan dengan keberanian seseorang untuk melaksanakan sesuatu kegiatan bisnis/non bisnis dengan peluang untung rugi.

Ada juga yang menyatakan bahwa wirausaha adalah keberanian atau juga kecakapan seseorang untuk menilai serta juga melihat suatu peluang dalam bisnis dan kemudian menyatukan suatu sumber daya yang diperlukan untuk pengambilan keputusan yang tepat dan tentunya mendapatkan keuntungan dalam rangka mencapai suatu keberhasilan.

Wirausahawan adalah seorang inovator yang mempunyai semangat, kemampuan, dan pikiran untuk menakklukkan cara berpikir lamban dan malas. Seorang wirausaha mempunyai peran untuk mencari kombinasi-kombinasi baru yang merupakan gabungan dari lima hal:

a. Pengenalan barang dan jasa baru.

b. Metode produksi baru.

c. Sumber bahan mentah baru.

d. Pasar-pasar baru, dan.

e. Organisasi Industri baru.

Berikut ini adalah keuntungan dari melakukan kegiatan wirausaha, yaitu:

1. Terbuka peluang untuk mencapai tujuan yang dikehendaki sendiri.

2. Terbuka peluang untuk mendemonstrasikan kemampuan serta potensi seseorang secara penuh.

3. Terbuka peluang untuk memperoleh manfaat dan keuntungan secara maksimal

4. Terbuka peluang untuk membantu masyarakat dengan usaha-usaha konkrit.

5. Terbuka kesempatan untuk menjadi bos.

Di samping keuntungan ternyata wirausaha memiliki beberapa kelemahan, yaitu:

1. Memperoleh pendapatan yang tidak pasti, dan memikul berbagai resiko. Jika resiko ini telah diantisipasi secara baik, maka berarti wirausaha telah menggeser resiko tersebut.

2. Bekerja keras dan waktu/ jam kerjanya panjang.

3. Kualitas kehidupannya masih rendah sampai usahanya berhasil, sebab dia harus berhemat.

4. Tanggung jawabnya sangat besar, banyak keputusan yang harus dia buat walaupun dia kurang menguasai permasalahan yang dihadapinya. 


\section{KEHIDUPAN SEHARI-HARI MASYARAKAT DUSUN SODONG}

Dusun Sodong adalah salah satu dusun yang berada paling Barat di Desa Gelangkulon. Dusun ini terletak di pegunungan yang berbeda dengan Dusun laiinya yang ada di Gelangkulon seperti Dusun Kroyo, Dusun Darat dan Dusun Gelang, sehingga di wilayah Dusun Sodong mayoritas jalan masih cor-coran dan banyak yang sudah rusak. Bahkan jalan menuju Dusun Sodong apabila melewati Balai Desa ke Barat masih bebatuan (makadam). Adapun batas wilayah Dusun Sodong adalah sebagai berikut:

Sebelah Utara : Desa Pagerukir

Sebelah Barat : Hutan

Sebelah Selatan : Hutan

Sebelah Timur : Hutan

Dusun Sodong termasuk salah satu dusun di desa Gelangkulon yang berada di pegunungan dan di kelilingi oleh hutan. Taraf hidup masyarakatnya adalah menengah ke bawah. Mayoritas warganya bekerja sebagai petani di sawah dan berkebun di hutan dekat pemukiman tempat tinggal mereka. Namun sawah mereka terletak jauh dan tidak berada di area Dusun Sodong. Lokasi Dusun Sodong yang berada di wilayah pegunungan mengakibatkan kurang terjangkaunya fasilitas umum seperti pasar, swalayan dan fasilitas umum lainnya, yang ada hanya toko kecil saja. Di dusun Sodong ini tidak ada area persawahan, yang banyak adalah area perkebunan dan hutan jati juga terdapat satu Masjid (Masjid Shirotol Mustaqim), satu SD (SDN 4 Gelangkulon), satu Vihara (Vihara Dharma Dwipa) dan pemakaman. Keunikan dusun Sodong adalah pluralnya masyarakat. Jika melihat lebih jauh ke dalam masyarakat, pluralitas ini tercermin dari kepercayaan masyarakat. Bukti dari dari ke-pluralan ini juga dapat dilihat dari toleransi tempat peribadatan di Sodong.

Kondisi ekonomi di Desa Gelangkulon terdapat berbagai profesi diantaranya: Pegawai Negeri/TNI/POLRI, pedagang, petani, buruh tani, tukang, dan pengusaha. Dan paling banyak adalah Petani, karena di desa gelang kulon terdapat banyak perkebunan salah satunya ada di dusun Sodong.

Mayoritas masyarakat Sodong bermata pencaharian sebagai petani. Mereka tinggal di daerah dengan kontur lahan yang sempit, kurang subur dan tidak mencukupinya air untuk irigasi, sawah sehingga menyebabkan masyarakat tidak dapat menaman padi, dan hanya bergantung dari palawija seperti jagung, kedela, singkong dan garut. Akibat dari keadaan tanah yang kurang subur meyebabkan warga dusun Sodong memproduksi berbagai macam camilan berupa rengginang 
singkong, kerupuk sermier dan emping garut sehingga para warga berinisiatif untuk membentuk UMKM (Usaha Mikro Kecil Menengah) demi mencukupi kehidupan hari-hari, akan tetapi dalam perkembangannya UMKM ini mengalami stagnasi dalam produksinya, hal ini disebabkan oleh beberapa faktor yakni karena kurangnya pasokan bahan yang diolah, hal disebabkan lamanya masa panen terutama tanaman singkong dan garut yang menjadi bahan pokok dalam produksi cemilan, selain itu hama tikus juga menjadi penyebab utama kurangnya bahan yang diproduksi. Faktor lainnya yaitu kurangnya pengetahuan pemasaran produk yang mereka buat.

Tabel 1.1 Potensi Sosial-Ekonomi Dusun Sodong

\begin{tabular}{clc}
\hline NO & MATA PENCAHARIAN & JUMLAH \\
\hline 1 & Pegawai Negeri/TNI/POLRI & 70 jiwa \\
\hline 2 & Pedagang & 6 jiwa \\
\hline 3 & Petani & 1.839 jiwa \\
\hline 4 & Buruh Tani & 80 jiwa \\
\hline 5 & Tukang & 25 jiwa \\
\hline 6 & Lain-lain & 2.248 jiwa \\
\hline & JUMLAH & $\mathbf{4 . 4 6 8}$ jiwa \\
\hline
\end{tabular}

Dari foktor-foktor penghambat tersebut membuat warga dusun Sodong bersama-sama berperan akif dalam mengatasi berbagai permasalahan terutama mengatasi hama tikus dan mereka berharap adanya pedampingan dari pemerintah, bukan hanya sekedar memberikan pelatihan-pelatihan saja akan tetapi mereka juga mengharapkan pendampingan secara intensif terhadap permasalahan-permasalahan yang mereka hadapi. Dengan begitu potensi-potensi ekonomi di dusun sodong ini menjadi lebih maju dan masyarakat dusun sodong dapat mengembangkan usaha mereka dengan berbagai olahan-olahan kreatif mereka.

Dusun Sodong dikepalai oleh seorang Kepala Dusun (Kamituwo) yang bernama Bapak Mulyono. Kepala Dusun tersebut mendapat intruksi langsung dari kepala Desa Gelangkulon. Adapun Kamituwo mempunyai intruksi langsung terhadap katua RW dan RT setempat.

Di Dusun Sodong terdiri dari 4 RT yaitu:

1) RT 01/RW 01 diketuai oleh Bapak Wahyudi

2) RT 02/RW 01 diketuai oleh Bapak Nardi

3) RT 01/RW 02 diketuai oleh Bapak Suryanto

4) RT 02/RW 02 diketuai oleh Bapah Narin 
Meskipun berada di daerah yang terpencil, dusun Sodong merupakan dusun yang dapat menjadi percontohan dalam hal kerukuran antar umat beragama. Di dusun ini meskipun berbeda agama dan keyakinan masyarakatnya hidup berdampingan tanpa ada kesenjangan diantara mereka. Mereka bersamasama membangun dusunnya dengan bergotong royong dan bermusyawarah, karena mereka sangat memegang erat sekali kerukunan yang sudah terjalin begitu baik.

Adanya perbedaan keyakinan inilah yang membuat dusun Sodong memiliki beragam kebudayaan, dikalangan umat islam di dusun Sodong dapat kita temui upacara-upacara kebudayaan kejawen dan sosial keagamaan semisal, kenduri (upacara kirim doa bagi orang tua yang sudah meninggal) mulai dari geblak, memperingati 7 hari, 40 hari, 100 hari dan 1000 hari, tingkepan (upacara penyambutan kelahiran anak), sepasar, aqiqoh, pitonan, dan lain sebagainya. Sedangkan dikalangan umat budha juga hampir sama dengan umat islam dalam memperingati upacara-upacara kenduri, tingkepan dan sebagainya selain aqiqoh. Prosesi berbagai upacara tersebut juga hampir sama yang membedakan adalah doanya, untuk kalangan umat islam doanya dipimpin oleh sesepuh umat islam serta doanya sesuai dengan ajaran islam sedangkan untuk umat budhapun juga dipimpin oleh sesepuh budha serta doanya sesuai dengan ajaran budha. Dalam perayaan hari rayapun umat islam dan umat budha juga saling berdampingan dalam menjalin kerukunan diantara mereka. Dikalangan umat islam ketika merayakan hari raya idhul fitri mereka bersilaturrahim dengan kalangan umat budha, dan ketika hari raya waisakpun umat budha juga bersilaturrahmi dengan umat islam, adat ini mereka sebut dengan anjangsana.

Selain itu dalam hal pelestarian kebudayaan asli daerah Ponorogo masih mereka pegang erat, setiap malam minggu mereka bersama-sama berlatih reogan dan karawitan baik dari kalangan orang tua dan pemuda. Meskipun peralatan yang mereka gunakan belum lengkap, tetapi antusias dalam melestarikan budaya sangat kuat sekali. Pusat pengembangan budaya reog dan karawitan berada di rumah salah satu warga Sodong dan vihara yang berada di dusun Sodong, hal ini membuktikan bahwa meskipun mereka berbeda keyakinan tetapi mereka bersama-sama mengembangkan bakat mereka guna melestarikan kebudayaan lokal agar dapat diturunkan kepada generasi muda mereka.

Masyarakat dusun Sodong merupakan masyarakat yang majemuk dalam keyakinan atau agamanya, persentase masyarakat yang memeluk agama Islam kurang lebih 60\% sedangkan yang memeluk agama budha kurang lebih 40\%. Di dusun sodong tidak ada istilah penyebaran agama karena menurut mereka penyebaran agama tidak cocok untuk diterapkan di Indonesia karena setiap 
orang pasti sudah mempunyai agama,dan istilah penyebaran pasti mempengaruhi orang untuk ikut agama yang dianutnya, akan tetapi di dusun sodong ini mengajarkan dan mengamalkan agama kepada umatnya sendiri sesuai agama yang dianutnya, sehingga antar umat beragama yang sudah ada tidak saling seretmenyeret. Meskipun ada perbedaan dalam keyakinan tidak menjadikan halangan bagi mereka untuk menjalankan sosial keagamaan yang mereka lakukan, karena rasa saling hormat dan menjalin kerukunan masih mereka pegang erat, sehingga menambah rasa antusias dalam menjalankan ibadah serta sosial agama yang mereka lakukan. Hal ini dibuktikan dengan adanya berbagai acara sosial keagamaan yang dilakukan umat islam maupun umat budha.

Kegiatan sosial keagamaan yang dilakukan umat islam antara lain yasinan ibuk-ibuk yang dilakukan setiap hari rabu. Kegiatan ini dilakukan secara bergilir dari rumah ke rumah, dan didampingi langsung oleh penyuluh KUA kecamatan Sampung, dalam kegiatan ini juga diadakan arisan sebagai bentuk pengikat kebersamaan antar warga, sedangkan yasinan bapak-bapak dilakukan kamis malam jum'at yang dipimpin oleh ketua ta'mir masjid setempat. Selain itu mereka juga melakukan kerja bakti setiap hari minggu, untuk bapak-bapak pada pagi hari dan untuk ibuk-ibuk sore hari. Sedangkan sosial keagamaan yang dilakukan umat budha antara lain namaskara (bentuk ibadah atau sembayang umat budha) di vihara yang dilakukan setiap minggu bersama ibu dan anak dan dalam namaskara umat budah menggunakan al-thar (media) berupa patung sang budha, bunga, dupa dan air, lalu dilanjut dengan sujud 3 (tiga) kali, lalu membaca kitab suci serta mediasi, namun namaskara juga bisa dilakukan setiap hari dirumah atau dimana saja, serta anjangsana (keliling kerumah umat) sebulan satu kali, dan kerja bakti di vihara setiap rabu.

\section{DIVERSIFIKASI MATA PENCAHARIAN MASYARAKAT}

Terisolasi bukan berarti keterbelakangan. Terisolasi juga bukan berarti pasrah akan nasib, tetapi terisolasi adalah sebuah muatan motivasi untuk lebih maju daripada lainnya. Alam sudah menakdirkan dirinya dimana dia akan membangun gunung, di mana dia akan membangun sungai, lautan, dan sebagainya. Manusia awalnya hanya bisa pasrah di mana dia akan ditempatkan, apakah di gunung, lautan, sungai, atau yang lainnya. Perbedaan bentang alam inilah yang menyebabkan berbedanya mata pencaharian masyarakat yang hidup di gunung (dataran tinggi) atau lautan (dataran rendah).

Perbedaan bentang alam menyebabkan perbedaan distribusi perihal fasilias hidup, akses kemudahan, tingkat penghasilan, pola pikir untuk berubah, dan sebagainya. Bagi masyarakat yang tinggal di bentang alam pegunungan umumnya 
menganggap dirinya terisolasi. Adanya anggapan seperti ini menimbulkan pandangan bahwasanya karena alam yang membatasi maka saya akan menerima dan memanfaatkan apapun yang diberikan oleh alam. Pola pikir dalam menyikapi relasi antara bentang alam dan jenis mata pencaharian sepertinya disikapi dengan kurang bijaksana. Jika semua disikapi bahwa karena isolasi bentang alam yang menjadikan masyarakat kurang berkembang, maka muaranya akan berakibat pada pasifnya penduduk. Penduduk hanya take it for granted terhadap apa yang ada di sekitar mereka. Mereka hanya mengolah tanah untuk tanaman pangan pokok semisal padi yang itu digunakan untuk konsumsi dan produksi.

Jika fenomena ini terjadi, apakah mereka pernah berpikir sampai kapan alam menyediakan kebutuhan hidup mereka? Tanah sudah tandus untuk padi, mineral sudah habis ditambang, ikan sudah habis mereka ambil. Dari sini kita harus memikirkan bersama apakah mereka sudah bisa hidup tanpa bantuan dari alam? Di sinilah seharusnya titik balik masyarakat untuk memikirkan alternatif mata pencaharian jika padi tidak lagi memberikan butirannya.

Untuk dapat mengubah kesadaran masyarakat akan pentingnya alternatif mata pencaharian $(\mathrm{baca}=$ wirausaha) sehingga dapat menambah penghasilan sampingan, maka diperlukan agen dari luar untuk membuka mindset dan memompa semangat berwirausaha masyarakat. Agen di sini hanya berfungsi sebagai narasumber dan jembatan penghubung antara masyarakat dengan jenis usaha yang akan diberdayakan.

Melihat geografi daerah Sodong dengan topografi dataran tinggi dan curah hujan yang sedikit maka perlu dicari jenis usaha apa yang cocok untuk lingkungan alam dan lingkungan sosial. Melihat gejala sosial yang ada di Sodong bahwa umumnya perempuan di sana hanya sebagai ibu rumah tangga tanpa penghasilan, maka seharusnya perlu dicarikan alternarif wirausaha yang dapat juga dikerjakan oleh kaum perempuan.

Dari hasil observasi dipastikan jenis usaha yang cocok adalah budidaya singkong gajah dan olahannya. Usaha budidaya singkong gajah dipilih karena umumnya lahan pekarangan masyarakat Mitir masih luas dan terkadang hanya dimanfaatkan untuk tanaman singkong biasa yang hasilnya jauh di bawah singkong gajah. Pertimbangan lainnya adalah budidaya singkong gajah tergolang ringan dan tidak menyita waktu aktivitas domestik sehingga dapat juga dikerjakan oleh kaum perempuan khususnya ibu rumah tangga sehingga diharapkan akan menambah penghasilan rumah tangga. Masyarakat Sodong juga mengenal baik cara bertanam singkong, karena sebelumnya mereka menanam singkong kualitas biasa. 
Untuk menindaklanjuti rencana budidaya singkong gajah di Sodong, maka segera disusun rencana kegiatan sosialisasi budidaya singkong gajah yang nantinya akan disosialisasikan di rumah warga dengan mengajak perwakilan masyarakat (bapak/ibu RT/RW). Perwakilan ini nanti diharapkan menjadi agen yang akan menyebarkan ilmu budidaya dan pengolahan hasil singkong gajah kepada seluruh warga masyarakan dusun Sodong. Berikut ini adalah proses dari rangkaian acara sosialisasi budidaya singkong gajah mulai dari tanam hingga panen dan pengolahan hasil panen.

Sebelum mempelajari cara menanam singkong gajah yang baik, terlebih dahulu harus mengetahui apa itu singkong gajah. Seperti yang sudah diketahui bahwa singkong merupakan salah satu tanaman yang sangat mudah untuk di tanam, terutama di Nusantara ini. Bagaimana tidak, kita tinggal menancapkan batang singkong di tanah dengan sendirinya dia akan tumbuh meskipun tanpa dilakukan perawatan.

Singkong gajah merupakan salah satu jenis singkong unggulan dari Kalimantan Timur yang mempunyai berat mencapai $40 \mathrm{~kg}$ per pohon. Tanaman ini bisa tumbuh dengan baik di dataran tinggi maupun dataran rendah, tetapi singkong tidak bisa tumbuh baik di daerah rawa atau tempat yang sering tergenang air.

Saat ini budidaya singkong menjadi salah satu alternatif pertanian untuk mendapatkan penghasilan lebih. Tingginya permintaan singkong untuk sekala industri sehingga membutuhkan singkong dalam jumlah besar. Hal ini bisa menjadi peluang usaha untuk membudidayakan tanaman singkong gajah.

Lokasi yang bagus untuk menanam singkong gajah yakni yang berada di ketinggian 10 sampai 700 meter di atas permukaan laut. Sedangkan curah hujan yang turun berkisar 1.500-2.500 mm/tahun dengan kondisi suhu udara minimal $10{ }^{\circ} \mathrm{C}$ dan kelembaban $60-65 \%$. Sedangkan bila ditanam di suhu kurang dari $10^{\circ} \mathrm{C}$ akan menyebabkan terhambatnya proses pertumbuhan.

Usahakan lahan tempat menanam berada di tempat yang terkena sinar matahari selama 10 jam setiap harinya. Hal ini akan berdampak baik untuk pertumbuhan dan kesuburan tanaman singkang gajah. Singkong gajah merupakan jenis tanaman yang mudah dibudidayakan di segala jenis lahan, asalkan tidak terendam air.

Daya tumbuh tanaman ini cukup mengagumkan, bahkan di lahan tanah berpasir kurang subur masih bisa menghasilkan umbi rata-rata $15 \mathrm{~kg} /$ batang. Untuk mendapatkan hasil terbaik Anda bisa menanamnya di tanah dengan tekstur remah, gembur, tidak terlalu liat, tidak terlalu berpori dan kaya bahan 
organik. Selain itu Anda juga harus memperhatikan keasaman tanah sesuai untuk budidaya singkong berkisar antara 4,5-8,0 dengan $\mathrm{pH}$ ideal 5,8.

Beberapa keunggulan tanaman singkong dibanding tanaman pertanian lain adalah sebagai berikut:

1. Daya tahan terhadap penyakit lebih kuat

2. Dapat bertahan hidup pada cuaca panas

3. Masa panen yang relatif lama sehingga bisa dijadikan untuk lumbung

4. Hampir semua bagian dari singkong dapat dimanfaatkan

Budidaya singkong dapat dilakukan dengan menggunakan biji dan stek, namun biasanya yang dilakukan masyarakat adalah menggunakan metode stek batang. Untuk menanam singkong gajah secara benar dapat dilakukan dengan beberapa cara berikut. Pertama, penyiapan bibit. Sebelum melakukan budidaya tanaman singkong gajah, perlu dilakukan pemilihan bibit yang berkualitas. Bibit singkong gajah yang akan dikembangbiakan dipilih berasal dari tanaman induk yang mempunyai karakteristik; produksi tinggi, kadar tepung tinggi, umur panen 7 - 9 bulan, tahan terhadap hama dan penyakit, warna putih, kadar sianida-nya rendah. Bibit dengan kualitas baik akan menghasilkan produksi yang tinggi dan kualitas singkong yang tinggi pula.

Pengembangbiakan tanaman singkong dapat dilakukan dengan cara stek. Batang tanaman singkong yang akan digunakan untuk stek dipilih berdasarkan umur kurang lebih 7-12 bulan, diameter 2,5-3cm, telah berkayu, lurus dan masih segar, panjang stek $20-25 \mathrm{~cm}$, bagian pangkal diruncingi agar memudahkan penanaman,kulit stek tidak terkelupas terutama pada bakal tunas. Kualitas dari bibit yang digunakan akan sangat berpengaruh pada pertumbuhan dan hasil budidaya singkong gajah, oleh kerena itu pastikan untuk memilih bibit terbaik. Berikut ini adalah foto masyarakat dusun sodong saat menyiapkan bibit singkong gajah.

Kedua, Menyiapkan Lahan Tanam dan Cara Tanam. Sebelum melakukan penanaman bibit singkong, maka perlu dilakukan pengolahan tanah terlebih dahulu agar tanah menjadi gembur sehingga pertumbuhan akar dan umbi berkembang dengan baik. Gulma dan sisa-sisa tanaman harus dibakar. Waktu mengerjakan tanah sebaiknya pada saat tanah tidak dalam keadaan becek atau berair, agar struktur tanah tidak rusak.

Curah hujan yang sesuai untuk tanaman singkong gajah antara $1.500-$ $2.500 \mathrm{~mm} /$ tahun. Kelembaban udara optimal untuk tanaman singkong gajah antara $60-65 \%$. Tanah yang paling sesuai untuk singkong gajah adalah tanah yang berstruktur remah, gembur, tidak terlalu liat dan tidak terlalu poros, serta kaya bahan organik. Tanah dengan struktur remah mempunyai tata udara yang 
baik, unsur hara lebih mudah tersedia, dan mudah diolah. Jenis tanah yang sesuai untuk tanaman singkong gajah adalah jenis aluvial, latosol, podsolik merah kuning, mediteran, grumosol, dan andosol.

Derajat kemasaman $(\mathrm{pH})$ tanah yang sesuai untuk budidaya singkong gajah berkisar antara 4,5 - 8,0 dengan $\mathrm{pH}$ ideal 5,8. Umumnya tanah di Indonesia ber$\mathrm{pH}$ rendah (asam), yaitu berkisar 4,0 - 5,5, sehingga seringkali dikatakan cukup netral bagi suburnya tanaman singkong gajah.

Ketinggian tempat yang baik dan ideal untuk tanaman ubi kayu antara 10$700 \mathrm{~m}$ dpl, sedangkan toleransinya antara 10-1.500 m dpl. Jenis singkong gajah tertentu dapat ditanam pada ketinggian tempat teretentu untuk dapat tumbuh optimal. Jika melihat geografis dusun Sodong, maka syarat ketinggian tanaman singkong gajah ini sangat memenuhi syarat.

Langkah awal dalam menyiapkan lahan tanam adalah dengan membersihkan lahan dari berbagai tanaman gulma, batu serta sisa-sia akar tanaman. Hal ini bertujuan untuk meminimalisir gangguan yang bisa menghambat pertumbuhan singkong gajah. Setelah lahan dibersihkan langkah selanjutnya adalah membuat tanah menjadi lebih gembur dengan cara di bajak. Pengolahan tanah dibajak atau di cangkul 1-2 kali sedalam kurang lebih $20 \mathrm{~cm}$, diratakan langsung ditanami atau di buat bedengan-bedengan atau guludan dan juga dibuat saluran drainase Buatlah bedengan untuk mempermudah perawatan tanaman singkong gajah. Pada proses ini berikan kaptan (dolomite) sebanyak 12.5 ton/ha, berikan kapur ini bersamaan dengan pemberian pupuk kandang. Sedangkan untuk masa pemupukan sebaiknya menggunakan pupuk cair organik MiG-6 Plus.

Dengan begitu maka penggunaan pupuk kimia akan berkurang sampai dengan 50\%. Secara tidak langsung hal tersebut akan menghemat biaya untuk pemupukan. 3 hari sebelum proses penanaman berikan 2 liter MiG-6 Plus dengan dosis 1 liter MiG-6 Plus dicampur 200 liter air. Semprotkan pupuk tersebut pada lahan yang akan ditanami singkong.

Setelah lahan siap maka selanjutnya adalah proses penanaman. Waktu tanam yang tepat bagi tanaman singkong gajah, secara umum adalah musim penghujan atau pada saat tanah tidak berair agar struktur tanah tetap terpelihara. Tanaman singkong gajah dapat ditanam di lahan kering, beriklim basah, waktu terbaik untuk bertanam yaitu awal musim hujan atau akhir musim hujan. Cara tanam singkong gajah jika dimaksudkan untuk diambil umbinya, penanaman stek dilakukan secara vertikal berjarak $50 \mathrm{~cm}$ antar stek. Namun, jika dimaksudkan untuk diambil daunnya, stek dapat ditanam rapat secara mendatar agar tunas baru muncul dari setiap buku. Anjuran cara tanam sebagai berikut : 
a) Pangkal stek dipotong rata atau runcing. Pangkal stek yang dipotong miring akan berdampak pada pertumbuhan akar yang tidak merata

b) Sebelum bibit ditanam sebaiknya dilakukan perendaman dahulu dengan menggunakan pupuk hayati MiG-6 Plus yang telah dicampur dengan air selama 3-4 jam.

c) Tanamlah stek dalam posisi vertical. Stek yang ditanam dalam posisi lain (miring 45 derajat dan horizontal), akarnya tidak terdistribusi secara merata. Volume akar di tanah dan penyebarannya berpengaruh pada jumlah hara yang dapat diserap tanaman, selanjutnya berdampak pada produksi. Jangan terbalik, pemotongan ujung stek meruncing, membantu agar stek tidak ditanam terbalik.

d) Kedalaman tanam $15 \mathrm{~cm}$, pada musim hujan maupun musim kemarau. Hal ini terkait dengan kelembaban tanah untuk menjaga kesegaran stek. Disarankan menanam dalam keadaan tanah gembur dan lembab. Tanah dengan kondisi ini akan menjamin kelancaran sirkulasi O2 dan CO2serta meningkatkan aktivitas mikrobia tanah. Keadaan ini dapat memacu pertumbuhan daun untuk menghasilkan fotosintesis secara maksimal yang akan ditranslokasikan ke tempat penyimpanan cadangan makanan (ubi) singkong gajah secara maksimal pula.

Ketiga, Pengolahan Hasil Panen Singkong Gajah. Pada pelatihan kewirausahaan "Kupas Singkong Gajah" di dusun Sodong, masyarakat juga diberikan pelatihan bagaimana mengolah hasil panen singkong gajah menjadi keripik renyah dan singkong kres. Berikut adalah proses pelatihan pembuatan kripik singkong renyah.

Untuk mendapatkan keripik singkong yang enak dan gurih, hal pertama yang harus anda lakukan atau anda pelajari adalah dalam memilih jenis singkong yang akan anda olah menjadi keripik singkong, ada banyak sekali jenis singkong yang bisa diolah menjadi keripik singkong, seperti singkong mentega, singkong gajah dan lain sebagainya, setiap singkong memiliki spesifikasi dan rasa yang berbeda-beda, bahkan ada singkong yang memiliki racun jika tidak di olah terlebih dahulu untuk menghilangkan racun nya.

Namun singkong yang paling bagus untuk membuat keripik singkong adalah singkong gajah karena rasanya yang enak, manis, dan teksturnya empuk ketika di makan, jadi tidak heran jika banyak orang yang mencari singkong jenis ini karena selain untuk keripik, singkong ini enak untuk di makan dalam keadaan di rebus atau digoreng dan dibuat tape. Ciri-ciri singkong yang bagus adalah ketika kulit singkong dikupas, daging singkong masih berwarna putih mulus dan tidak ada brecak garis berwarna biru atau lain nya. 
Bahan Dalam Membuat Keripik Singkong Yang Renyah: Bahan:

- $1 \mathrm{~kg}$ singkong yang masih segar

- 1 sendok makan kapur sirih

- $250 \mathrm{ml}$ air

Bumbu yang di haluskan:

- 3 sendok makan garam halus

- 1 sendok makan gula pasir.

- 8 butir bawang merah.

- 4 siung bawang putih.

- minyak untuk menggoreng secukupnya.

Proses Pembuatan Keripik Singkong; Singkong yang sudah dipilih dan masih segar harus dikupas kulitnya terlebih dahulu, kemudian cuci singkong yang sudah dikupas tersebut dengan air hingga benar-benar bersih. Iris singkong tipis-tipis dan sama ukurannya agar mudah ketika menggoreng, sehinga kematangan merata, tidak ada yang kurang matang atau gosong nantinya. Gunakan alat pemotong keripik singkong serbaguna agar potongan bisa bagus dan tidak membutuhkan waktu lama untuk mengirisnya, jika tidak punya, anda bisa menggunakan pisau yang tajam agar irisan nya bagus, namun membutuhkan waktu yang lebih lama. Kemudian masukkan singkong yang sudah diiris tipistipis ke dalam air yang sudah anda tambahkan kapur sirih agar singkong tersebut nantinya akan lebih renyah rasanya.

Setelah itu haluskan bumbu yang sudah ada di atas, dan setelah halus, bisa memasukkannya ke dalam rendaman singkong tersebut, lalu aduk hingga merata dan diamkan selama kurang lebih 1 jam. Kemudian angkatlah singkong yang sudah direndam tadi dan tiriskan hingga tidak ada air yang menempel atau hingga keripik tersebut kering tanpa harus di jemur di bawah matahari. Setelah itu panaskan minyak di atas api sedang, kemudian goreng singkong yang sudah kering tadi hingga matang atau krispi. Saat di goreng jangan lupa sambil diaduk agar singkong tersebut tidak menempel satu sama lain. Kemudian angkat dari penggorengan dan tiriskan. Setelah itu tunggu keripik singkong tersebut agar tidak ada minyak yang menempel atau hingga keripik dingin. Setelah itu anda bisa menambahkan bumbu tambahan seperti pedas. Setelah itu anda bisa memasukkan keripik tersebut ke dalam wadah plastik sesuai takaran dan pres ujung plastik agar keripik singkong bertahan lebih lama. 


\section{KESIMPULAN}

Hasil kegiatan pengabdian masyarakat tentang budidaya singkong gajah yang diselenggarakan di dusun Sodong, Kec. Sampung, Kab. Ponorogo, dapat disimpulkan: masyarakat diharapkan memiliki keinginan yang kuat untuk berdiri sendiri; memiliki kemauan untuk mengambil resiko; memiliki kemampuan untuk belajar dari pengalaman; memiliki kemampuan untuk memotivasi diri; kemampuan untuk bersaing; memiliki orientasi pekerja keras; memiliki rasa percaya diri; dan memiliki dorongan untuk maju dan berprestasi. Dengan demikian, masyarakat secara mandiri dapat mengembangkan diri dan mengtasi problem yang dihadapi.

\section{DAFTAR PUSTAKA}

Alma. Buchari. Kewirausahaan. Bandung: Alfabeta. 2017.

BPS Kabupaten Ponorogo.Statistik Daerah Kecamatan Badegan 2016. Ponorogo:

BPS Kabupaten Ponorogo, 2016.

Kasali, Rhenalds. Wirausaba Muda Mandiri. Jakarta:Gramedia Pustaka Utama. 2011.

Poerwadarminta.WJS. Kamus Umum Bahasa Indonesia Jakarta: Balai Pustaka, 1999. Soekanto Soerjono.SosiologiSuatu Pengantar. Jakarta: PT. Raja Grafindo Persada. 2015.

Soehadi. Agus, dkk. Enterpreneurship Education. Jakarta: Prasetya Mulya Publishing. 2011.

Suherman, Eman. Desain Pembelajaran Kewirausahaan. Bandung: Alfabeta. 2008. 
Berdamai dengan Hutan ...

Hendra Afiyanto 